\title{
DMS production in a coccolithophorid bloom: evidence for the importance of dinoflagellate DMSP lyases
}

\author{
Michael Steinke ${ }^{1, *}$, Gill Malin ${ }^{1}$, Stephen D. Archer ${ }^{2}$, Peter H. Burkill ${ }^{2}$, Peter S. Liss ${ }^{1}$ \\ ${ }^{1}$ School of Environmental Sciences, University of East Anglia, Norwich NR4 7TJ, United Kingdom \\ ${ }^{2}$ Plymouth Marine Laboratory, Prospect Place, West Hoe, Plymouth PL1 3DH, United Kingdom
}

\begin{abstract}
During an experiment in the North Atlantic in June 1998, water samples were collected approximately $400 \mathrm{~km}$ south of Iceland inside and outside of a bloom of the coccolithophorid Emiliania huxleyi. In vitro dimethylsulphoniopropionate (DMSP) lyase activity (DLA) was quantified using gas chromatography and found to vary from 0.1 to $142.3 \mathrm{nM}$ dimethyl sulphide (DMS) $\mathrm{h}^{-1}$. Inside the bloom area the majority of DLA (>74\%) occurred in particles $>10 \mu \mathrm{m}$, indicating that $E$. huxleyi (5 to $7 \mu \mathrm{m}$ diameter) made only a minor contribution to total DLA. In surface waters, phototrophic dinoflagellates $(>10 \mu \mathrm{m})$ made up a high proportion of the total phytoplankton biomass $(\sim 27 \%)$ towards the end of the coccolithophorid bloom and may have been the source of most of the DLA. This was also indicated by a significant correlation $(p<0.02)$ between DLA and the concentration of peridinin, a pigment used as a chemotaxonomic marker for dinophytes. The data presented here are the first field measurements of DLA in a coccolithophorid bloom and suggest that even a relatively low concentration of photosynthetic dinoflagellates larger than $10 \mu \mathrm{m}$ (during our study 18 to $105 \mathrm{cells} \mathrm{ml}^{-1}$ ) may contribute significantly to DMS production. Although dinoflagellates are recognised as an important source of particulate DMSP, recognition of their significance for DMS production in the field has previously been limited to a few observations in highly concentrated coastal and shelf blooms. Very little information exists on DLA in dinophytes and further investigations are warranted in order to improve our understanding of the biogeochemical and ecophysiological significance of DMSP lyases in this group of phytoplankton.
\end{abstract}

KEY WORDS: DMSP lyase - Dimethyl sulphide - DMS - Dinoflagellates · Coccolithophorids · Emiliania huxleyi $\cdot$ North Atlantic

\section{INTRODUCTION}

Biological activity is the main source of oceanic dimethyl sulphide (DMS), a volatile compound that is of considerable importance in the global sulphur cycle (Lovelock et al. 1972). DMS influences atmospheric acidity and is thought to play a significant role in climate regulation (Charlson et al. 1987). The major precursor of this biogenic gas is dimethylsulphoniopropionate (DMSP), a compatible solute found in various groups of marine algae, particularly the dino-

*E-mail: m.steinke@uea.ac.uk phytes and haptophytes (Keller 1989). The abiotic conversion of DMSP to DMS, acrylate and a proton is slow at seawater $\mathrm{pH}$, and alternative precursors are considered to be of minor importance for DMS production. Therefore, enzymatic cleavage by DMSP lyase (dimethylpropiothetin dethiomethylase; enzyme classification [EC] number 4.4.1.3.) is thought to be the major process for DMS production in marine environments.

DMSP lyase isozymes have been found in various marine organisms including bacteria (de Souza \& Yoch 1995, van der Maarel et al. 1996), a fungus (Bacic \& Yoch 1998), and micro- and macroalgae (Cantoni \& Anderson 1956, Kadota \& Ishida 1968, Stefels \& van 
Boekel 1993, Steinke et al. 1996, 1998, Niki et al. 2000, Wolfe 2000). The role of algal DMSP lyases is being investigated and it has been suggested that this isozyme is important for the osmotic acclimation of algal cells via the degradation of DMSP (Stefels 2000). Additionally, the build-up of acrylate within the microzone or mucus layer surrounding a cell (Noordkamp et al. 2000) may result in concentrations harmful to microbial organisms (Sieburth 1960, Slezak et al. 1994). Intracellular DMSP lyases are probably segregated from their substrate so that DMS production is only initiated following cell damage (Wolfe \& Steinke 1996). Furthermore, the grazing-induced production of DMS and acrylate has been suggested as the basis of a chemical defence mechanism in phytoplankton (Wolfe et al. 1997).

It is assumed that DMS is produced via a complex network of processes within the marine microbial foodweb, but the relative contributions of prokaryotes and eukaryotes to DMSP turnover to DMS is still unclear. Recently, pathways for non-bacterial production of DMS have been more widely acknowledged. The findings of a modelling study showed that omission of algal DMS production led to an underestimate of the sea-to-air flux by up to $25 \%$ (van den Berg et al. 1996). Additionally, the relationship of DMS production with mixing layer depth and its similarities to photosynthetic activity suggest that the role of phytoplankton in DMSP-to-DMS conversion is greater than recognised (Simó \& Pedrós-Alió 1999a).

The haptophyte coccolithophorid Emiliania huxleyi accumulates millimolar concentrations of intracellular DMSP, and in vitro enzyme assays showed high DMSP lyase activity (DLA) (12 to $25 \mathrm{fmol} \mathrm{DMS} \mathrm{cell}{ }^{-1} \mathrm{~min}^{-1}$; Steinke et al. 1998, values corrected as described in Steinke et al. 2000) in isolates from the English Channel and the Sargasso Sea. Additionally, blooms of this phytoplankton species can cover large areas and change the optical properties of surface waters, resulting in the characteristic reflectance signals detected by satellites (Brown \& Yoder 1994). Several research cruises that focussed on regions with E. huxleyi blooms have demonstrated the importance of these areas for the production of DMSP and DMS (Holligan et al. 1993, Malin et al. 1993, Matrai \& Keller 1993, Simó \& Pedrós-Alió 1999b) and contributed to our understanding of DMSP/DMS production, transformation and cycling.

The present study formed part of the Atmospheric Chemistry Studies in the Oceanic Environment (ACSOE) North Atlantic Experiment 1998 (Liss et al. unpubl.), which investigated the biogeochemical controls and cycling of a variety of marine trace gases. Despite the knowledge that the enzymatic cleavage of DMSP is the major pathway for DMS production, only very few measurements of enzyme activity have been carried out in the field (Stefels et al. 1995) and the ecophysiology of this reaction is not well understood. In this paper we present the first data for particulate DLA within a bloom of the coccolithophorid Emiliania huxleyi. We hypothesised that this species is the most important producer of DMS in a typical North Atlantic coccolithophorid bloom and, hence, would contribute most of the DLA. Measurements of DLA were conducted in tandem with analysis of a suite of biological parameters in order to identify the source of the DMSP lyase. Our results suggest that dinoflagellates, although low in numerical abundance, can be an important source of DLA in the field.

\section{MATERIALS AND METHODS}

Sampling. Water samples were taken inside and outside a bloom of the coccolithophorid Emiliania huxleyi during cruise D234 of RRS 'Discovery' between 14 June and 3 July 1998 (Table 1). The bloom was located in the centre of an anticyclonic eddy (40 to $50 \mathrm{~km}$ diameter) at approximately $59.5^{\circ} \mathrm{N}$ and $21.1^{\circ} \mathrm{W}(\sim 400 \mathrm{~km}$ south of Iceland; Fig. 1). In common with other coccolithophore bloom areas (e.g., Balch et al. 1991) and in contrast with the surrounding waters, the eddy core was characterised by high water-leaving radiance at $555 \mathrm{~nm}$ as seen in SeaWiFS satellite images (Fig. 1) and relatively low chlorophyll (chl) a concentrations. The inert tracer sulphur hexafluoride $\left(\mathrm{SF}_{6}\right)$ was deployed within a few kilometres of the eddy centre on 13 June ( 7 to $9 \mathrm{~m}$ depth, 7 by $7 \mathrm{~km}$ area). The initial patch moved towards the northeast during 14 to 27 June and was re-injected with tracer on 22 June. Daily surveys were conducted with a semi-automated analytical system connected to the ship's seawater supply (intake at $\sim 4 \mathrm{~m}$ depth) in order to locate the centre of the $\mathrm{SF}_{6}$ patch (Nightingale et al. 2000). Sampling stations were positioned where the highest concentrations of $\mathrm{SF}_{6}$ were encountered. Further general information about the study will be presented by Liss et al. (in preparation).

A conductivity, temperature, depth rosette sampler (CTD) was used to collect discrete water samples in Niskin bottles from various depths. Samples were immediately gravity filtered through a $200 \mu \mathrm{m}$ Nitex screen while transferring the water into 21 polycarbonate bottles. Water samples were kept in low light at $12^{\circ} \mathrm{C}$ for a maximum of $1 \mathrm{~h}$ before proceeding with further filtrations onto polycarbonate filters.

Filter fractionations and storage of DLA samples. An experimental set-up similar to the gravity filtrations detailed in Stefels et al. (1995) was used to gently 


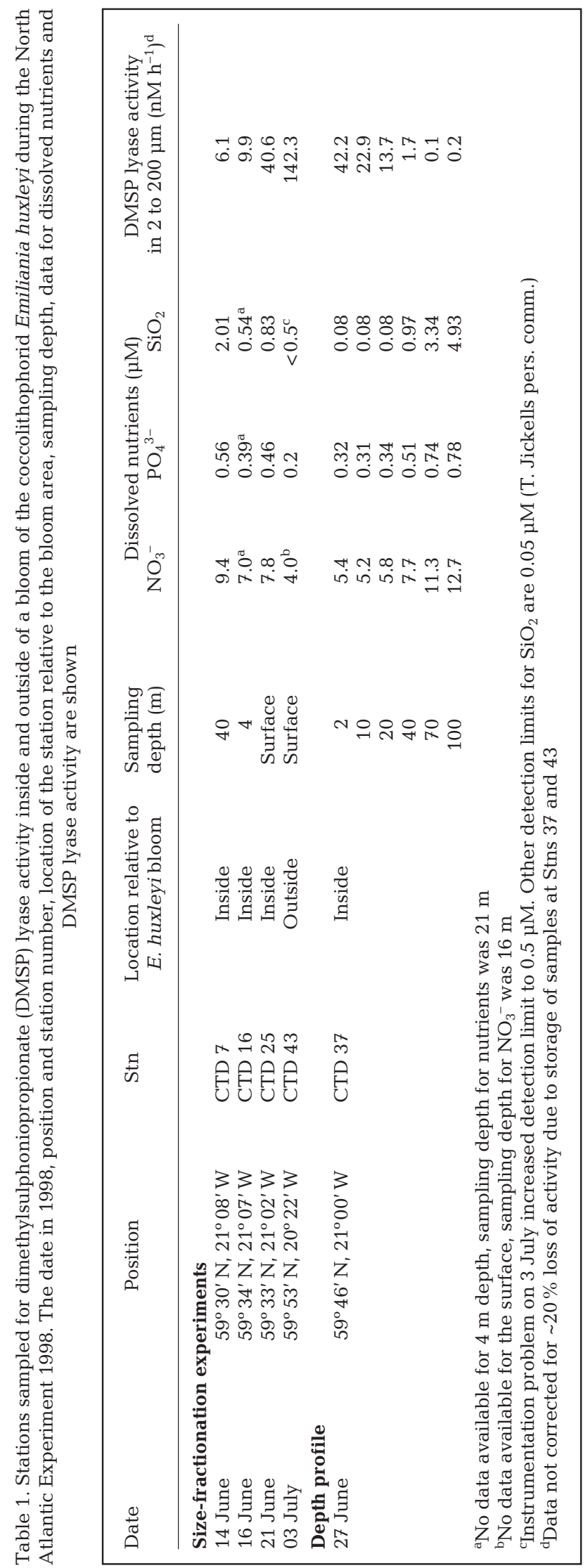

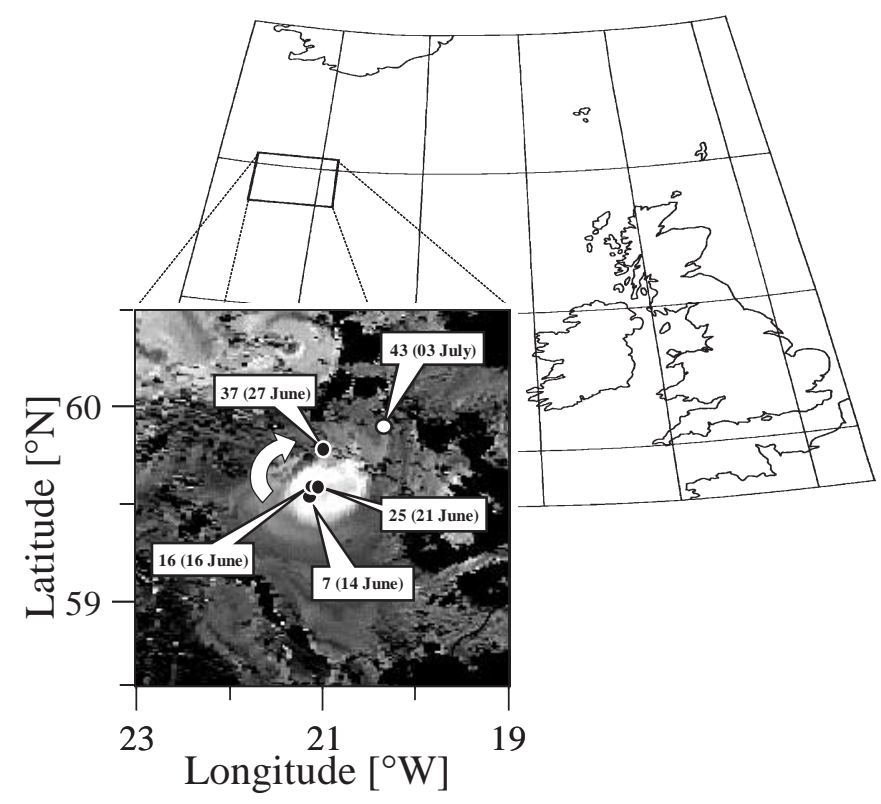

Fig. 1. Outline map of the Northeast Atlantic Ocean indicating the study area (box south of Iceland). The inset shows a composite SeaWiFS satellite picture (14 and 16 June 1998) depicting water-leaving radiance at $555 \mathrm{~nm}$, which indicates high light scattering from coccoliths in the centre of an Emiliania huxleyi bloom at $59.5^{\circ} \mathrm{N}$ and $21.1^{\circ} \mathrm{W}$. Black areas represent locations with complete cloud coverage. Sampling stations are pointed out in black and white circles and labels give station numbers and date in 1998. Note that CTDs 7 to 37 were in the same water mass that was moved to the northeast by clockwise turning of the eddy (indicated by the white arrow) during 14 to 27 June

concentrate particles from 1.3 to $4 \mathrm{l}$ of $200 \mu \mathrm{m}$ prefiltered seawater. Three $100 \mathrm{ml}$ size fractions were collected using $47 \mathrm{~mm}$ diameter polycarbonate filters as follows: for CTDs 7 and 16 the size fractions used were 2 to 5,5 to 10 and 10 to $200 \mu \mathrm{m}$, and for CTDs 25 and 43 the size classes were modified to 2 to 5,5 to 18 and 18 to $200 \mu \mathrm{m}$. The remaining $<2 \mu \mathrm{m}$ filtrate was concentrated to $100 \mathrm{ml}$ over a $0.2 \mu \mathrm{m}$ filter under low vacuum $(<100 \mathrm{mmHg})$. Particles attached to the 10, 5, 2 and $0.2 \mu \mathrm{m}$ or $18,5,2$ and $0.2 \mu \mathrm{m}$ filters were gently resuspended in the concentrate before subsamples for measurement were taken of $\mathrm{chl} a$ and particulate DMSP $\left(\right.$ DMSP $\left._{\mathrm{p}}\right)$ concentrations, and to confirm successful fractionation using analytical flow cytometry (AFC). For DLA analysis, the remaining concentrates were filtered onto their respective polycarbonate filters under low vacuum. Further 1.3 to 2.11 aliquots of seawater were filtered with low vacuum to investigate particulate DLA in 2 to $200 \mu \mathrm{m}$ particles at all stations. All filtrations were carried out under dim light at $12^{\circ} \mathrm{C}$. Filtration time was dependent on biomass and sample volume, and required 15 to $30 \mathrm{~min}$ (vacuum filtrations) or 2 to $4 \mathrm{~h}$ (gravity filtrations). DLA was measured 
either immediately or after snap-freezing of filters in liquid nitrogen and storage at $-80^{\circ} \mathrm{C}$ for $3 \mathrm{~d}$ (CTD 37 ; vertical profile) or 4 mo (CTD 43 ; size fractionation). Methodology tests showed that storage time did not affect DLA but freezing resulted in $\sim 20 \%$ loss of activity compared to DLA measurements carried out immediately after sampling (Steinke et al. 2000).

DLA measurements. The particles collected on polycarbonate filters were analysed for DLA with a method used to test the activity of DMSP lyase isozymes in different strains of Emiliania huxleyi (Steinke et al. 2000). In brief, filters were extracted by sonication in 1.5 to $1.7 \mathrm{ml}$ of ice-cold $344 \mathrm{mM}$ citric acid/phosphate buffer with $500 \mathrm{mM}$ sodium chloride at $\mathrm{pH} 6$. The resulting crude extract was directly used in the enzyme tests. Filters prepared at 8 stations north of the study area discussed here were stored frozen and analysed for DLA in 2 to $200 \mu \mathrm{m}$ particles after the cruise in order to investigate methodological and analytical variability. DLA ranged from 5 to $32 \mathrm{nM} \mathrm{h}^{-1}$, and the average relative variation between duplicates gave a methodological uncertainty of $\pm 12 \%$ (range of relative variation was \pm 2 to $24 \%, \mathrm{n}=16$ ). The analytical precision was calculated from pseudo-duplicates (2 DLA measurements from the same filter, $\mathrm{n}=32$ individual analyses) and showed an average relative variation of $\pm 2.7 \%$ with a range of \pm 0.3 to $6.3 \%$.

After addition of $20 \mathrm{mM}$ DMSP (final concentration), the DMS production was monitored for 45 to $258 \mathrm{~min}$, depending on the activity of DMSP lyase, at room temperature $\left(22.5\right.$ to $\left.26.6^{\circ} \mathrm{C}\right)$. Controls with buffer alone were used to quantify abiotic DMS production. The time-course of DMS concentration in the headspace of the vials was investigated using on-column injections (50 $\mu$ l of headspace sample) into a GC-14 gas chromatograph (Shimadzu) fitted with a Chromosil 330 packed column (Supelco) and flame-photometric detector. A series of known concentrations of commercial DMSP (Centre for Analysis, Spectroscopy and Synthesis [CASS], University of Groningen Chemical Laboratories, The Netherlands) in $10 \mathrm{M}$ sodium hydroxide were used for calibration (Steinke et al. 2000).

Seawater DMS and DMSP measurements. The same gas chromatography system as above was used to quantify DMS and $\mathrm{DMSP}_{\mathrm{p}}$ in $3 \mathrm{ml}$ water samples using a purge-and-trap system as described by Turner et al. (1990). Calibrations were carried out with dilutions of a primary standard prepared gravimetrically from commercial DMSP (CASS), which were prepared in distilled water, filter sterilised $(0.2 \mu \mathrm{m})$ and stored frozen.

Pigment analyses. A fluorometric method (Parsons et al. 1984) was used to determine chl a concentrations in size-fractionated samples. Applying a low vacuum,
$20 \mathrm{ml}$ of the concentrates were filtered through glass fibre filters ( $25 \mathrm{~mm}$ diameter, Whatman GF/F). Filters were snap-frozen in liquid nitrogen and stored at $-80^{\circ} \mathrm{C}$. Pigments were extracted for $24 \mathrm{~h}$ at $-20^{\circ} \mathrm{C}$ in the dark, using $20 \mathrm{ml} 90 \%$ (v/v) acetone. To maximise the chl a extraction yield, filters were vigorously shaken on a vortex mixer immediately and $12 \mathrm{~h}$ after immersion in acetone.

For a vertical profile at station CTD 37, phytoplankton pigments were analysed using a reversephase HPLC technique as described in Gibb et al. (2000). Briefly, 2.151 of sample was filtered through a glass fibre filter (25 mm diameter, Whatman GF/F). Filters were stored in liquid nitrogen until pigments were extracted in $100 \%$ methanol with the aid of sonication. Pigments were separated on a Hypersil MOS2 C-8 column (Shandon, Runcorn, UK), using a binary mobile phase/linear gradient and isocratic hold (70:30\% methanol:1 M ammonium acetate/100\% methanol at $1 \mathrm{ml} \mathrm{min}^{-1}$ ). Peak detection was by absorbance at $440 \mathrm{~nm}$ and quantification with respect to a canthaxanthin internal standard via relative response factors.

Flow cytometry. For the filter-fractionation experiments, flow-cytometric counts were carried out on size-fractionated concentrates and whole water samples with a FACSort flow cytometer (Becton Dickinson) equipped with a $15 \mathrm{~W}$ laser exciting at $488 \mathrm{~nm}$ and a standard filter set-up. Parameters were collected as logarithmic signals, and graphs were drawn and analysed using the WinMDI freeware (Joseph Trotter, Scripps Research Institute, La Jolla, CA, USA). Phytoplankton were identified by a combination of red fluorescence (>650 nm), orange fluorescence (585 $\pm 21 \mathrm{~nm})$ and $90^{\circ}$ light scatter. A laboratory-grown culture (strain 92E, Plymouth Culture Collection) was used as a reference to identify lithed Emiliania huxleyi cells in natural waters.

Microscopic cell counts at CTDs 25, 37 and 43. After the cruise, phytoplankton were identified and cells were counted on settled 10 to $100 \mathrm{ml}$ samples preserved in either $4 \%$ formaldehyde or iodine Lugol's solution with an inverted microscope using $\times 200$ and $\times 400$ magnification. Carbon estimates for each species were derived from volume determinations (Kovala \& Larrance 1966) and the cell volume/carbon relationships given by Eppley et al. (1970).

Bacterial abundance, biomass and production at CTD 37. Samples for bacterial abundance determination were fixed with $1 \%$ paraformaldehyde and $0.5 \%$ glutaraldehyde, incubated for $10 \mathrm{~min}$, snap-frozen in liquid nitrogen and stored at $-70^{\circ} \mathrm{C}$. After thawing, samples were stained for 10 min with $2.5 \mu \mathrm{M}$ Syto 13 (Molecular Probes) and analysed with a FACScalibur flow cytometer (488 nm laser; Beckton Dickinson) 
using yellow-green $0.92 \mu \mathrm{m}$ latex beads (Polysciences, Eppelheim, Germany) as internal standards. Bacterial size was calculated after the average fluorescence of the bacterial population was normalised to that of the beads (calibration by comparison to image analysis of epifluorescence preparations following Massana et al. 1997) and converted to biomass. Bacterial production was determined through the incorporation of ${ }^{3} \mathrm{H}$-thymidine (Fuhrman \& Azam 1982) as described in Pedrós-Alió et al. (1999). Samples were incubated with $20.4 \mathrm{nM}{ }^{3} \mathrm{H}$-thymidine, a final concentration that was found to be saturating in a wide range of open marine environments (PedrósAlió et al. 1999).

\section{RESULTS}

Initial satellite images, AFC cell counts and concentrations of the major nutrients $\mathrm{NO}_{3}{ }^{-}$and $\mathrm{PO}_{4}{ }^{3-}$ (Table 1) suggested that the coccolithophorid bloom could develop to higher cell densities over the period proposed for our observations. Furthermore, the hydrographic conditions in the eddy centre allowed us to deploy the tracer $\mathrm{SF}_{6}$ in order to track the same water mass until the end of our study. Hydrographic data and $\mathrm{SF}_{6}$ tracer information indicate that CTDs 7 , 16,25 and 37 were inside the same water mass, whereas CTD 43 was in a different water mass outside of the investigated bloom area (Fig. 1; Liss et al. unpubl.). Phytoplankton counts for the period of 14 to 19 June (stations not sampled for DLA but within the investigated eddy) confirm the dominance of coccolithophorids, which contributed 35 to $65 \%$ of total phytoplankton carbon in surface waters. High winds on 19 June induced mixing and homogenisation of the water column to $80 \mathrm{~m}$, well below the depth of the previous nutricline. After the storm, stations inside the tracked water mass (21 and 27 June) showed lower coccolithophorid biomass with 18 and $10 \mathrm{mg} \mathrm{C} \mathrm{m}^{-3}$ (Table 2) or 28 and $12 \%$ of total phytoplankton carbon, respectively, and the ratio of detached coccoliths to intact coccospheres (Table 3; Balch et al. 1991, Matrai \& Keller 1993) suggested that the coccolithophore bloom was probably in a late stage by midJune. In contrast to this, dinoflagellate biomass increased from 9 to $26 \%$ of phytoplankton carbon at these stations, and the shift from a coccolithophorid to a dinoflagellate-dominated phytoplankton assemblage corresponded with an increase in DLA at the surface. Inside the bloom area DLA increased from $9.9 \mathrm{nM} \mathrm{h}^{-1}$ (16 June) to $42.2 \mathrm{nM} \mathrm{h}^{-1}$ (27 June) in surface waters. Samples from a station on 3 July (CTD 43 ; different water mass) showed higher DLA of $142.3 \mathrm{nM} \mathrm{h}^{-1}$ (Table 1).

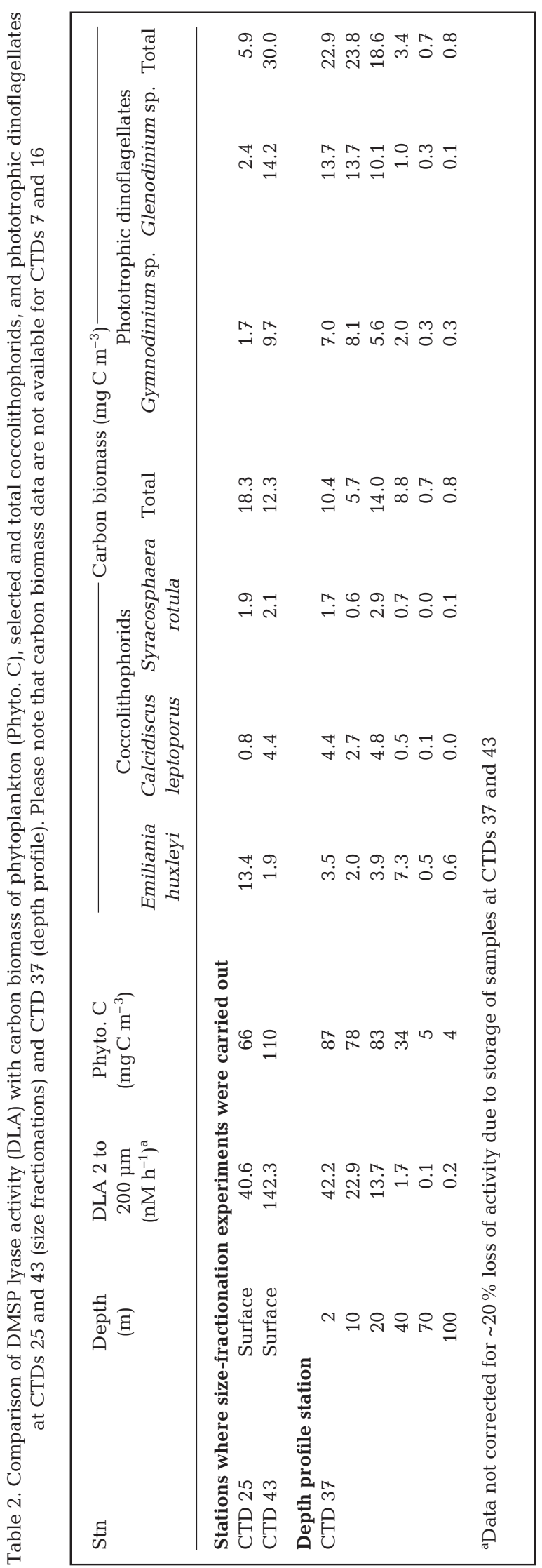




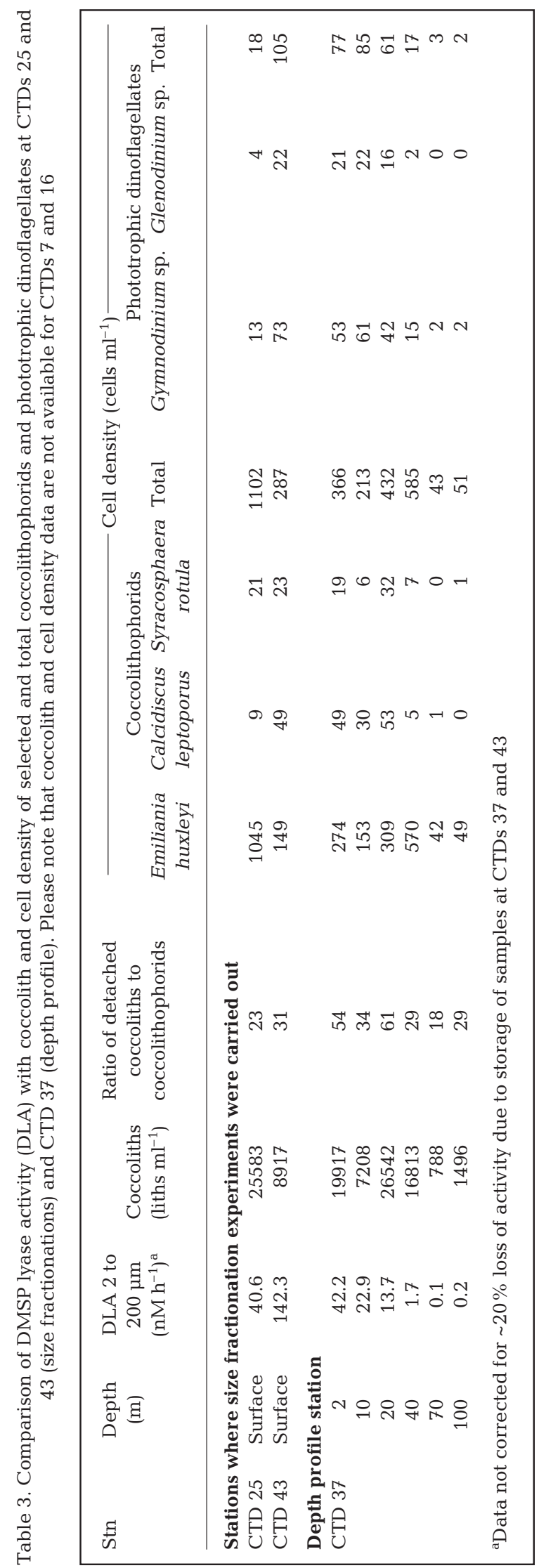

\section{Size-fractionation experiments}

In water samples used for size fractionations, DLA ranged from 6.1 to $142.3 \mathrm{nM} \mathrm{h}^{-1}$ in the 2 to $200 \mu \mathrm{m}$ fraction (Table 1). The analyses for CTDs 37 and 43 probably underestimate DLA by about $20 \%$ due to loss of activity during freezing and storage of filters (Steinke et al. 2000). Relative distributions of DLA, DMSP $_{\mathrm{p}}$, Emiliania huxleyi cells and chl a between the size fractions was similar for CTDs 7, 16 and 25, despite sampling from different depths and changing filter pore sizes (Fig. 2). The highest DLA was always associated with the biggest size class. At CTDs 7 and 16, particles from 10 to $200 \mu \mathrm{m}$ accounted for $75 \%$ and $80 \%$ of the total DLA, respectively (Fig. 2A,B). DLA decreased in the next 2 smaller size classes ( 5 to 10 and 2 to $5 \mu \mathrm{m}$ ) and showed values of $4 \%$ and $2 \%$ in the smallest size class $(0.2$ to $2 \mu \mathrm{m})$. Flow cytometric counts of E. huxleyi cells were highest in the fraction corresponding to the 5 to $10 \mu \mathrm{m}$ particle sizes $(83 \%$ and $60 \%$, respectively, of the total) and indicate good separation of particles into the respective size classes. Although $8 \%$ and $39 \%$ of E. huxleyi cells were found in the largest size class (10 to $200 \mu \mathrm{m})$, cell numbers were low in the 2 smaller size classes ( 2 to 5 and 0.2 to $2 \mu \mathrm{m})$. Most of the $\mathrm{DMSP}_{\mathrm{p}}(>84 \%)$ and chl a (>57\%) was found in the 2 biggest size classes (5 to 10 and 10 to $200 \mu \mathrm{m})$.

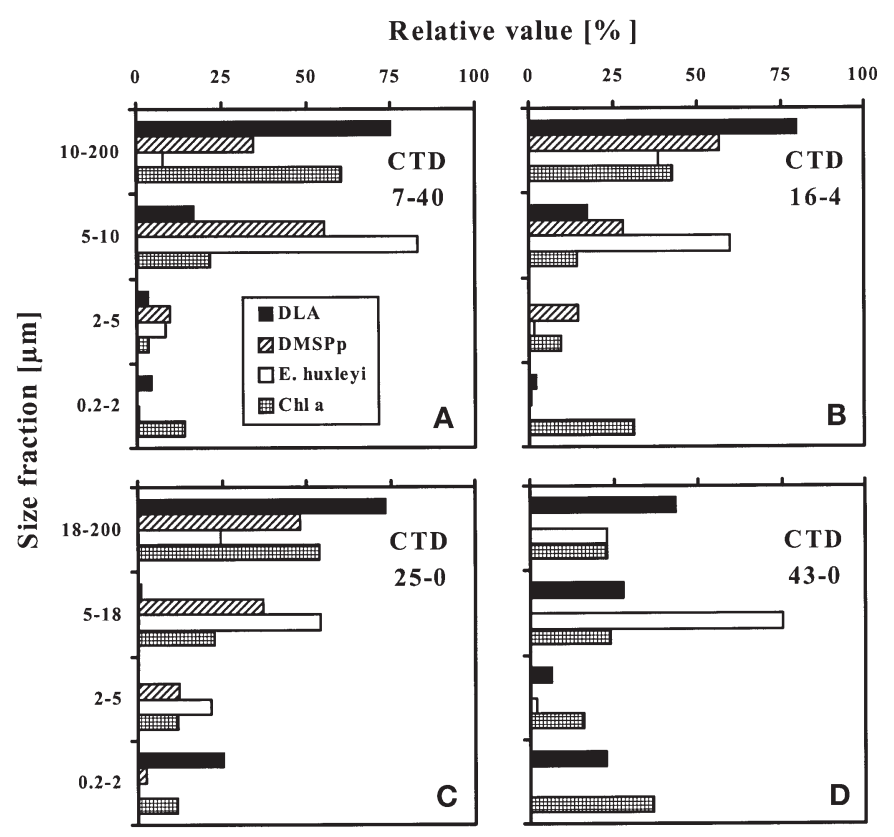

Fig. 2. Relative values for dimethylsulphoniopropionate (DMSP) lyase activity (DLA), particulate DMSP (DMSP ${ }_{\mathrm{p}}$ ) concentration, Emiliania huxleyi density and chlorophyll a (chl a) concentration in size-fractionated samples. (A) CTD 7 (40 m depth), (B) CTD 16 (4 m depth), (C) CTD 25 (surface) and (D) CTD 43 (surface) 
Since Emiliania huxleyi cell counts were high in the largest size class at CTD 16, we used a filter with $18 \mu \mathrm{m}$ pore size instead of a $10 \mu \mathrm{m}$ filter at CTDs 25 and 43 (Fig. 2C,D). Despite this methodological change, the general patterns of investigated parameters were similar at CTD 25 to those reported for CTD 7 and CTD 16. DLA accounted for $74 \%$ in the biggest size class, although it was relatively higher for the 0.2 to $2 \mu \mathrm{m}$ particles (25\%). Maximum E. huxleyi cell numbers were found in the 5 to $18 \mu \mathrm{m}$ size class (54\%). At CTD 43 (outside the bloom), DLA in the largest size class was less $(43 \%)$ but higher in the 5 to $18 \mu \mathrm{m}$ fraction $(28 \%)$ than at the other stations.

For CTDs 25 and 43, microscopic cell counts were conducted on preserved samples and phytoplankton carbon biomass was calculated (Tables 2 \& 3). Coccolithophorids showed high densities at both stations and were dominated by Emiliania huxleyi (5 to $7 \mu \mathrm{m}$ diameter), Calcidiscus leptoporus (20 $\mu \mathrm{m}$ diameter) and Syracosphaera rotula (5 to $7 \mu \mathrm{m}$ diameter). The phototrophic dinoflagellates were dominated by Gymnodinium sp. (30 $\mu \mathrm{m}$ length) and Glenodinium sp. (20 $\mu \mathrm{m}$ length) but their cell densities were low relative to the density of E. huxleyi cells. However, the carbon biomass of dinoflagellates was similar to the coccolithophorid biomass at CTD $25\left(5.9 \mathrm{mg} \mathrm{C} \mathrm{m}^{-3}\right)$ but 2.4fold higher (30 $\mathrm{mg} \mathrm{C} \mathrm{m}^{-3}$ ) than the biomass of coccolithophorids at CTD 43. Flow-cytometric counts of bacterio- and picoplankton indicated low cell numbers for Synechococcus sp. and picoeukaryotes at 3 of the 4 CTD stations (CTDs 7, 16 and 25: range $<500$ to 4668 Synechococcus cells $\mathrm{ml}^{-1}$ and $<500$ to 4800 picoeukaryote cells $\mathrm{ml}^{-1}$ ). However, at CTD 43 (surface) cell densities increased to 38922 and 7540 cells ml-1, respectively.

\section{Depth profile at CTD 37}

The temperature and salinity distributions at CTD 37 revealed a mixed layer from the surface to about $25 \mathrm{~m}$ depth, where rapid temperature and salinity changes indicated a transition into the thermo- and halocline zones (Fig. 3A). Most of the DLA was confined to the mixed layer and activity increased towards the surface (maximum value $42.2 \mathrm{nM} \mathrm{h}^{-1}$; Table 1). DMSP $\mathrm{p}$ concentration was highest at $10 \mathrm{~m}$ depth (93 nM) and DMS showed a maximum at $20 \mathrm{~m}$ depth (4 nM; Fig. 3B). The carbon biomass of phytoplankton and bacteria indicated a uniform distribution within the mixed layer (surface to $20 \mathrm{~m}$ depth: averages of 83 and $13 \mathrm{mg} \mathrm{C}$ $\mathrm{m}^{-3}$, respectively) but bacterial heterotrophic production was highest at 10 and $20 \mathrm{~m}$ depth (33.2 and 33.6 $\mu \mathrm{g} \mathrm{C} \mathrm{m}^{-3} \mathrm{~h}^{-1}$ ) and $34 \%$ lower at the surface (21.9 $\mu \mathrm{g} \mathrm{C} \mathrm{m}^{-3} \mathrm{~h}^{-1}$; Fig. 3C).
Measurements of phytoplankton pigment concentrations showed variable distribution patterns (Fig. 3D). Values for chl a were similar throughout the mixed layer (surface to $20 \mathrm{~m}$ depth: average $717 \mu \mathrm{g} \mathrm{m}^{-3}$ ) and comparable to measurements in a coccolithophorid bloom in 1991 (300 to $1000 \mu \mathrm{g} \mathrm{m}^{-3}$; Holligan et al. 1993). Concentrations of 19'-hexanoyloxyfucoxanthin (hex-fuco), a pigment characteristic for Emiliania huxleyi and other haptophytes (Jeffrey et al. 1997), were highest at $20 \mathrm{~m}$ depth $\left(353 \mu \mathrm{g} \mathrm{m}^{-3}\right)$ and lower at the surface (306 $\mu \mathrm{g} \mathrm{m}^{-3}$ at $2 \mathrm{~m}$ depth). The characteristic pigment for dinoflagellates, peridinin, showed the opposite trend: high at the surface $\left(37 \mu \mathrm{g} \mathrm{m} \mathrm{m}^{-3}\right)$ and lower at $20 \mathrm{~m}$ depth. Linear regressions $(\mathrm{n}=6)$ between DLA and the pigments $\operatorname{chl} C_{1}$, $\operatorname{chl} C_{2}$, chl $C_{3}$, fucoxanthin and hex-fuco were characterised by non-
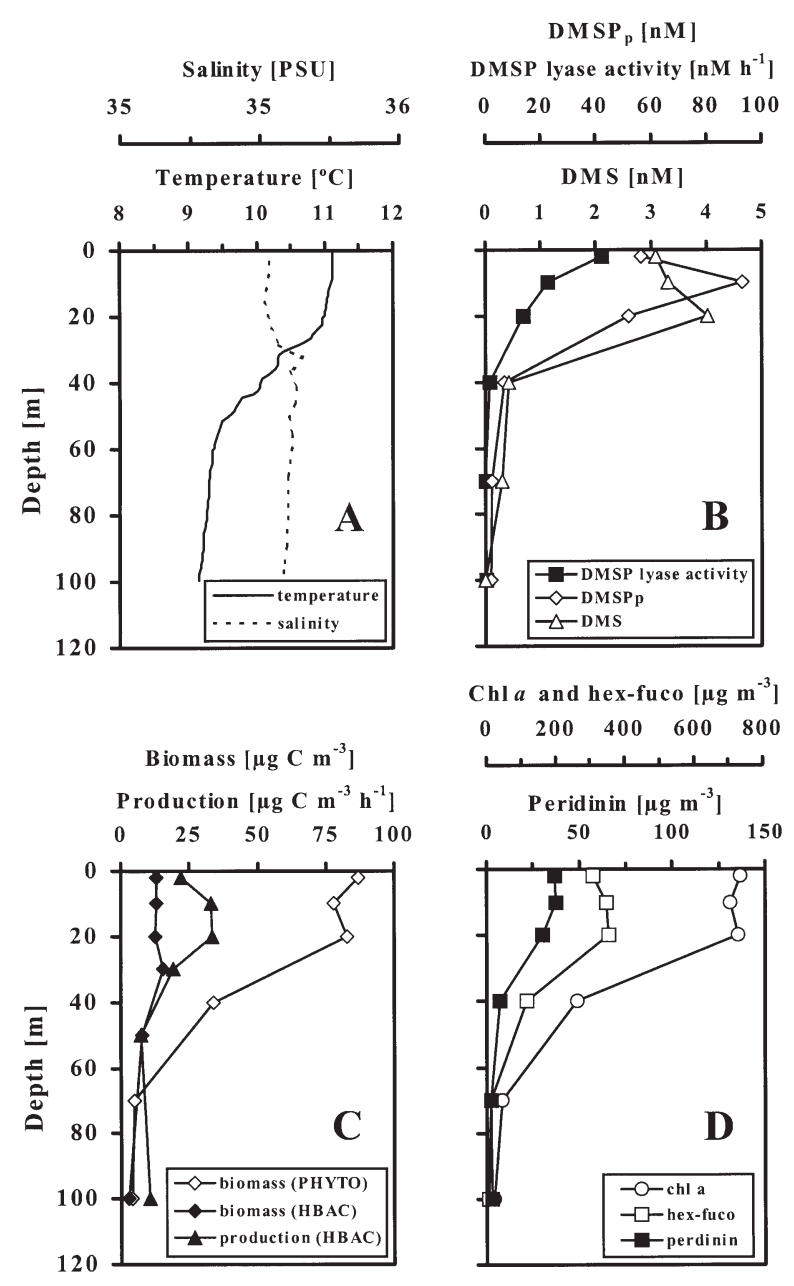

Fig. 3. Hydrographic and biological parameters at depth profile station CTD 37. (A) Salinity and temperature, (B) DMSP lyase activity (DLA), DMS and DMSP concentration, (C) carbon biomass of phytoplankton (PHYTO) and heterotrophic bacteria (HBAC), and production of HBAC and (D) concentration of selected phytoplankton pigments ( $\mathrm{chl} a$, 19' hexanoyloxyfucoxanthin [hex-fuco], peridinin) 


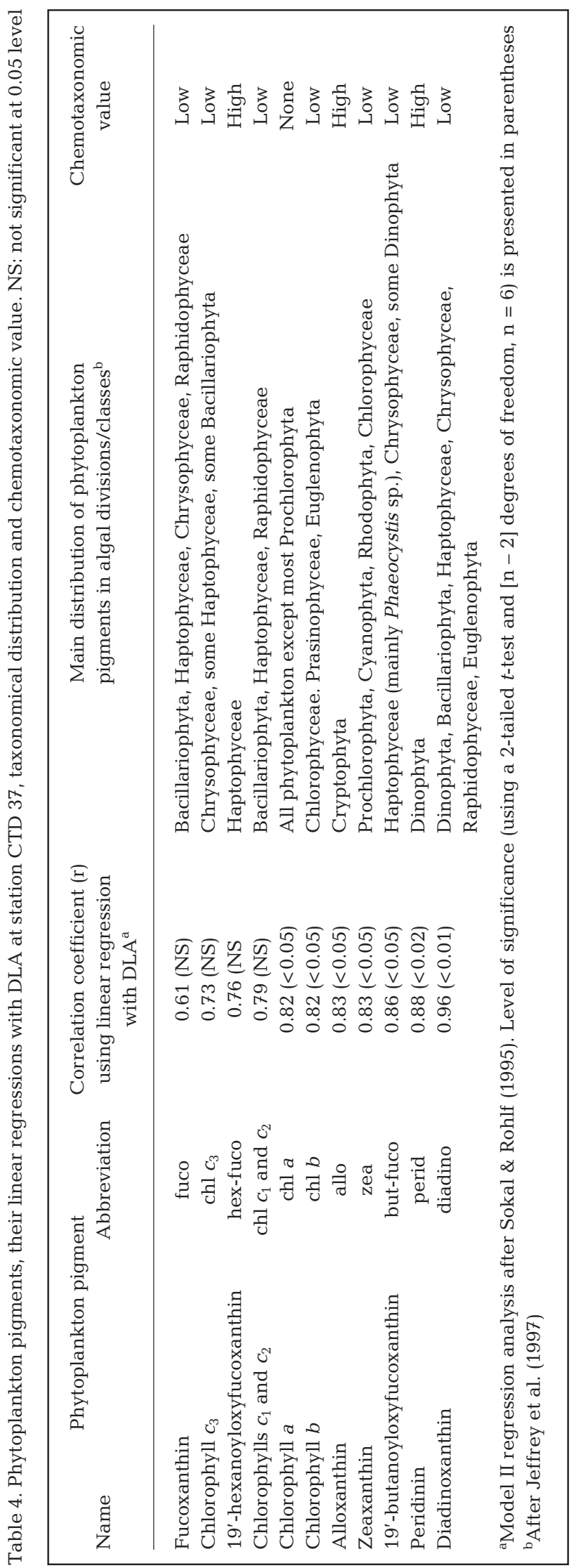

significant relationships $(\mathrm{p} \geq 0.05)$ and low correlation coefficients $(r \leq 0.79)$ (Table 4). The relationships between DLA and $\operatorname{chl} a$, chl $b$, alloxanthin, zeaxanthin and 19'-butanoyloxyfucoxanthin (but-fuco) indicated better coefficients $(\mathrm{r}=0.82$ to 0.86 ; $\mathrm{p}<0.05$ ) but correlations of higher significance were only found with diadinoxanthin (diadino; $\mathrm{r}=0.96 ; \mathrm{p}<0.01$ ) and the dinoflagellate-specific peridinin $(r=0.88 ; p<0.02)$. Regression analyses of phytoplankton biomass with

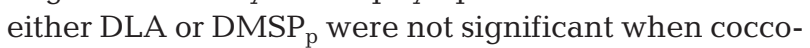
lithophorid biomass was used ( $\mathrm{r}<0.1$; Fig. 4A), but significant for phototrophic dinoflagellates (DLA: $\mathrm{r}=0.88, \mathrm{p}<0.05 ;$ DMSP $_{\mathrm{p}}$ : $\mathrm{r}=0.96, \mathrm{p}<0.01$; Fig. 4B).

Emiliania huxleyi was numerically the most abundant coccolithophorid at all sampling depths with highest densities below the mixed layer at $40 \mathrm{~m}$ depth (570 cells $\mathrm{ml}^{-1}$; Table 3 ). The other significant coccolithophorid species, Calcidiscus leptoporus and Syracosphaera rotula, were relatively low in numbers but contributed substantially to the carbon biomass at depths of $2 \mathrm{~m}\left(6.1 \mathrm{mgC} \mathrm{m}^{-3} ; 57 \%\right.$ of total cocco-

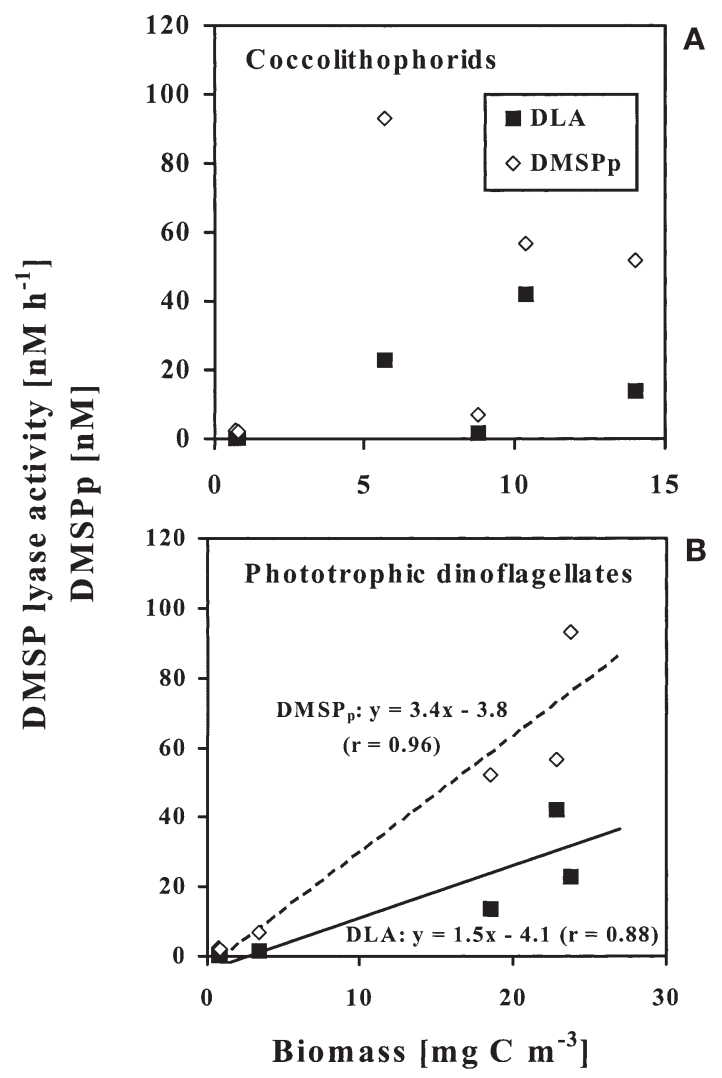

Fig. 4. Relationships between (A) coccolithophorid and (B) phototrophic dinoflagellate biomass with DMSP lyase activity (DLA) and $\mathrm{DMSP}_{\mathrm{p}}$ at CTD 37. Linear regressions are indicated by the dashed line $\left(\mathrm{DMSP}_{\mathrm{p}}\right.$ : $\left.\mathrm{p}<0.01\right)$ and solid line (DLA: $p$ < 0.05) using a Model II analysis after Sokal \& Rohlf (1995) 
lithophorid carbon), $\left.10 \mathrm{~m} \mathrm{(3.3} \mathrm{mg} \mathrm{C} \mathrm{m}^{-3} ; 58 \%\right)$ and $20 \mathrm{~m}\left(7.7 \mathrm{mgC} \mathrm{m}^{-3} ; 55 \%\right)$. Although the density of phototrophic dinoflagellates was low (2 to $20 \mathrm{~m}$ depth, average 74 cells $\mathrm{ml}^{-1}$ ), they represented a high proportion of the phytoplankton carbon biomass with 22.9 (26\% of total phytoplankton biomass), 23.8 (30\%) and $18.6(22 \%) \mathrm{mg} \mathrm{C} \mathrm{m}^{-3}$ at 2, 10 and $20 \mathrm{~m}$ depth, respectively, and were dominated by Gymnodinium sp. and Glenodinium sp. Picoplankton carbon biomass was similar to the biomass of the dinoflagellates (2 to $20 \mathrm{~m}$ average of $25.9 \mathrm{mg} \mathrm{C} \mathrm{m}^{-3}$ ) but the diatom biomass was relatively low ( 2 to $20 \mathrm{~m}$ average of $11.9 \mathrm{mg} \mathrm{C} \mathrm{m}^{-3}$ ), which is in agreement with the low silicate concentrations found at this station.

\section{DISCUSSION}

At 5 stations in the Northeast Atlantic Ocean, DLA was measured in particles of various size classes. Maximum activity was associated with particles $>10 \mu \mathrm{m}$ and, surprisingly, not in the size fraction corresponding to the coccolithophorid Emiliania huxleyi. This phytoplankton was numerically the most abundant species, has been shown to be a major producer of DMSP (Keller 1989, Malin et al. 1994) and has strain-specific DLA ranging from 0.004 to $25 \mathrm{fmol}$ DMS cell ${ }^{-1} \mathrm{~min}^{-1}$ (Steinke et al. 1998, values corrected as described in Steinke et al. 2000). Preliminary data on cell-specific DLA in 3 clonal isolates of E. huxleyi from CTD 44 (20 m depth, 4 July 1998, $21 \mathrm{~km}$ southwest of CTD 43) indicate relatively low average activities of $0.04 \mathrm{fmol} \mathrm{DMS}$ cell ${ }^{-1} \mathrm{~min}^{-1}$.

\section{Are dinoflagellates contributing to the DMS production in coccolithophorid blooms?}

It is often assumed that coccolithophorid blooms are almost mono-specific and that Emiliania huxleyi is of great importance for the production of DMS, especially towards the end of a bloom (Matrai \& Keller 1993). However, in samples collected towards the later stages of the bloom (CTDs 25, 37 [2, 10 and $20 \mathrm{~m}$ ] and 43), dinoflagellate biomass was generally greater than that of E. huxleyi (Table 2). There is evidence that some dinoflagellates not only may be important producers of DMSP (Keller 1989) but also can enzymatically convert DMSP to DMS (Kadota \& Ishida 1968, Steinke et al. 1996, Niki et al. 2000, Wolfe 2000). Furthermore, our measurements indicate that phototrophic dinoflagellates could have been the main source of $\mathrm{DMSP}_{\mathrm{p}}$ and DMSP lyase at CTD 37 (Fig. 4B), whereas coccolithophorid biomass was not significantly correlated with either of these parameters (Fig. 4A). Using our data for total DLA at CTDs 25, 37 (2,10 and $20 \mathrm{~m})$ and
43, we can calculate cell-specific DLA in the phototrophic dinoflagellates after making the following assumptions: (1) E. huxleyi and phototrophic dinoflagellates are the only sources of DLA and (2) cellspecific DLA in E. huxleyi is $0.04 \mathrm{fmol} \mathrm{cell}^{-1} \mathrm{~min}^{-1}$ (as indicated for clonal isolates at station CTD 44). With these presumptions the dinoflagellates contributed a cell-specific DLA of 3.5 to $35.3 \mathrm{fmol} \mathrm{cell}^{-1} \mathrm{~min}^{-1}$, which is in good agreement with the activities reported for phototrophic dinoflagellates such as Alexandrium sp. ( 40 $\mu$ m diameter; Wolfe 2000).

Size-fractionation data also provide evidence that larger phytoplankton, such as the dominating dinoflagellates Gymnodinium sp. (30 $\mu \mathrm{m}$ length) and Glenodinium sp. (20 $\mu \mathrm{m}$ length), produced DMSP lyase. The flow-cytometric counts showed that most of the Emiliania huxleyi cells were successfully fractionated into the 5 to 10 and 5 to $18 \mu \mathrm{m}$ size classes. Despite this, the highest percentage of DLA was found in the largest size classes (10 to 200 and 18 to $200 \mu \mathrm{m}$ ), which most likely had a high amount of dinoflagellate carbon biomass. The use of size-fractionated assays coupled with taxonomic analysis provides a simple means of estimating the relative importance of major taxa or functional groups in DMSP lyase production in natural assemblages. Although manipulation of samples can result in artefacts, particularly when long filtration times are necessary for gentle separation of particles, we found that vacuum size fractionations carried out in parallel with gravity filtrations at CTD 7 resulted in poor size separation with an artificially high number of small particles and $90 \%$ of DLA collected on the filter with the largest pore size $(10 \mu \mathrm{m})$. Therefore, we decided to use gravity filtrations in the size-fractionation experiments and believe that this is the best possible approach available.

The pigment data for CTD 37 confirm the outcome of our size-fractionation experiments and provide further evidence for the importance of dinoflagellates for potential DMS production in the investigated area at the time of this study. Peridinin, characteristic of dinoflagellates, was significantly correlated $(p<0.02)$ to DLA in samples from the depth profile (Table 4). Interestingly, diadinoxanthin was also closely correlated $(p<0.01)$ to DLA activity. Diadinoxanthin is a photoprotective pigment in the 2-component xanthophyll cycle of some phytoplankton, which is necessary for the thermal dissipation of light energy under high irradiance levels.

\section{Influence of bacterial DMSP lyases}

The interpretation of our field results is complicated by the fact that heterotrophic bacteria can also be a 
source of DLA (de Souza \& Yoch 1995, van der Maarel et al. 1996). DMSP lyases from unattached bacteria were probably concentrated in the smaller size fractions. Indeed, in samples from CTDs 25 and 43, about $24 \%$ of total DLA activity was found in the 0.2 to $2 \mu \mathrm{m}$ size class. Additionally, we cannot eliminate the possibility that particle-attached bacteria may have resulted in relatively high bacterial DLA in the larger size fractions. However, in the depth profile at CTD 37, productivity of heterotrophic bacteria was high at 10 and $20 \mathrm{~m}$ depths but relatively low close to the surface. In contrast to this, DLA was 1.8 and 3 times higher at $2 \mathrm{~m}$ than at 10 and $20 \mathrm{~m}$ depths, respectively. This suggests that bacterial production and DLA were not closely linked and, hence, bacteria were probably not the primary source of DMSP lyase at this station.

Little is known about the role of cyanobacteria in DMS production. Corn et al. (1996) reported that the contribution of prokaryotes to total $\mathrm{DMSP}_{\mathrm{p}}$ in a timeseries experiment in the Mediterranean Sea and 3 areas of the subtropical Atlantic Ocean was negligible. In contrast to this, a mesocosm study suggested that the cyanobacterium Synechococcus may produce high $\mathrm{DMSP}_{\mathrm{p}}$ concentrations (Wilson et al. 1998). It is unknown whether phototrophic bacteria are also a source of DMSP lyase.

\section{Vertical distribution of DLA}

The biological parameters measured at the depth profile station (CTD 37) indicate that most of the biological activity was restricted to the mixed layer (above $25 \mathrm{~m}$ depth; Fig. 3C,D). However, the phytoplankton counts suggest that the density of Emiliania huxleyi was high at about $40 \mathrm{~m}$ depth (Table 3 ). This contrasts with the relatively low concentrations of hex-fuco and chl $a$ at this depth. Additionally, flow-cytometric cell counts were lower than microscopic cell counts at CTD 38 ( $5 \mathrm{~h}$ after CTD 37 and in the same water mass inside the E. huxleyi bloom area). Therefore, it is possible that some of the particles that were seen in the microscope counts were empty coccospheres sinking through the thermocline below the euphotic zone (1\% light level at $30 \mathrm{~m}$ depth; G. Moncoiffé pers. comm.).

It is intriguing that highest DMS concentrations did not coincide with the depth of maximum DLA. Therefore, how our measurements of in vitro DLA (i.e., the potential for DMS production) relate to DMS production in situ remains unclear (see discussion in Steinke et al. 2000). Parallel measurements of DMS production rates in short-term $(24 \mathrm{~h})$ incubation experiments were much lower than the potential for DMS production and ranged from 0.05 to $0.6 \mathrm{nM} \mathrm{DMS} \mathrm{h}{ }^{-1}$ (Simó \& PedrósAlió 1999b). Several production and loss processes, such as photochemical oxidation, microbial consumption and sea-to-air transfer, influence the concentration of DMS. Particularly microzooplankton grazing (Wolfe \& Steinke 1996) and viral lysis (Bratbak et al. 1995, Malin et al. 1998) can be important factors for the conversion of DMSP to DMS in coccolithophorids. The vertical distribution of DMSP lyases could also be affected by species-specific production of this enzyme. Similar specificity has been shown for the accumulation of DMSP in various phytoplankton taxa (Keller 1989), and species associated with the ocean surface may provide proportionally more DLA than the phytoplankton below. Furthermore, high light intensity at the surface not only may influence phytoplankton pigment composition (e.g., accumulation of xanthophyll cycle pigments such as diadinoxanthin) but also could affect the physiology of DMSP lyases. In a coccolithophorid bloom in the northern North Sea in 1999, the ratio of DLA to chl a showed a similar pattern to the ratio of diadinoxanthin to $\mathrm{chl} a$, and the highest values were always associated with the surface (Steinke et al. 2002). However, detailed studies on the effect of environmental factors (temperature, light, nutrients, etc.) on DMSP lyase physiology are unavailable. This lack of information will be addressed in our future investigations.

In summary, our results provide evidence that dinoflagellates were an important source of DLA and by extension they could also have been significant for the conversion of DMSP to DMS during the latter stages of the coccolithophorid bloom. These findings reinforce indirect evidence from other studies that related dinoflagellate abundance with DMS production (Turner et al. 1988, Leck et al. 1989). Cell-specific DLA in Emiliania huxleyi appeared to be relatively low in this particular bloom (0.04 fmol DMS cell-1 $\mathrm{min}^{-1}$ ) and dinoflagellates with high DLA per cell may contribute to the increased concentrations of DMS associated with the demise of such coccolithophorid blooms.

Acknowledgements. The authors thank the captain and crew of RRS 'Discovery' for their assistance during cruise D234, which was part of the Natural Environment Research Council's (NERC) Atmospheric Chemistry Studies in the Oceanic Environment (ACSOE) Thematic Programme. We are also grateful to our colleagues, especially Wendy Broadgate (coordination of the cruise), Phil Nightingale, Fiona Carse and Malcolm Liddicoat (deployment and tracking of $\mathrm{SF}_{6}$ ), Marie Hamren-Larssen and Gareth Lee (chlorophyll analyses), Russell Davidson (phytoplankton enumeration) and Jane Read (physical oceanography). Stuart Gibb, Carlos Pedrós-Alió and Tim Jickells are acknowledged for making their results on phytoplankton pigments, heterotrophic bacteria and nutrients available. SeaWiFS images were captured and archived by the NERC Satellite Receiving Station, Dundee, and processed by the Remote Sensing Group, Plymouth Marine Laboratory (data are courtesy of the NASA SeaWiFS Project and Orbital Science Corporation). We also appreciate the comments of 3 
anonymous referees whose suggestions greatly improved an earlier version of this paper. Financial support for this study was provided by NERC (GR3/10956, GT5/98/8/MS and GST/02/1278), the UK Defence Evaluation and Research Agency (DERA/SESS/C21.10) and the European Union's IRONAGES project (EVK2-CT1999-00031). This is a NERC ACSOE publication number ACP159.

\section{LITERATURE CITED}

Bacic MK, Yoch DC (1998) In vivo characterization of dimethylsulfoniopropionate lyase in the fungus Fusarium lateritium. Appl Environ Microbiol 64:106-111

Balch WM, Holligan PM, Ackleson SG, Voss KJ (1991) Biological and optical properties of mesoscale coccolithophore blooms in the Gulf of Maine. Limnol Oceanogr 36:629-643

Bratbak G, Levasseur M, Michaud S, Cantin G, and 3 others (1995) Viral activity in relation to Emiliania huxleyi blooms: a mechanism of DMSP release? Mar Ecol Prog Ser 128:133-142

Brown CW, Yoder JA (1994) Coccolithophorid blooms in the global ocean. J Geophys Res Oceans 99:7467-7482

Cantoni GL, Anderson DG (1956) Enzymatic cleavage of dimethylpropiothetin by Polysiphonia lanosa. J Biol Chem 22:171-177

Charlson RJ, Lovelock JE, Andreae MO, Warren SG (1987) Oceanic phytoplankton, atmospheric sulphur, cloud albedo and climate. Nature 326:655-661

Corn M, Belviso S, Partensky F, Simon N, Christaki U (1996) Origin and importance of picoplanktonic DMSP. In: Kiene RP, Visscher PT, Keller MD, Kirst GO (eds) Biological and environmental chemistry of DMSP and related sulfonium compounds. Plenum, New York, p 191-201

de Souza MP, Yoch DC (1995) Purification and characterization of dimethylsulfoniopropionate lyase from an Alcaligenes-like dimethyl sulfide-producing marine isolate. Appl Environ Microbiol 61:21-26

Eppley RW, Reid FMH, Strickland JDH (1970) Estimates of phytoplankton crop size growth rate and primary production. In: Strickland JDH (ed) The ecology of the plankton off La Jolla, California in the period April through September 1967. Bull Scripps Inst Oceanogr 17:33-42

Fuhrman JA, Azam F (1982) Thymidine incorporation as a measure of heterotrophic bacterioplankton production in marine surface waters: evaluation and field results. Mar Biol 66:109-120

Gibb SW, Barlow RG, Cummings DG, Rees NW, and 3 others (2000) Surface phytoplankton pigment distributions in the Atlantic Ocean: an assessment of basin scale variability between $50^{\circ} \mathrm{N}$ and $50^{\circ} \mathrm{S}$. Prog Oceanogr 45:339-368

Holligan PM, Fernandez E, Aiken J, Balch WM, and 11 others (1993) A biogeochemical study of the coccolithophore Emiliania huxleyi in the North Atlantic. Global Biogeochem Cycles 7:879-900

Jeffrey SW, Mantoura RFC,Wright SW (1997) Phytoplankton pigments in oceanography: guidelines to modern methods. UNESCO, Paris

Kadota H, Ishida Y (1968) Effect of salts on enzymatical production of dimethyl sulfide from Gyrodinium cohnii. Bull J Soc Sci Fish 34:512-518

Keller MD (1989) Dimethyl sulfide production and marine phytoplankton: the importance of species composition and cell size. Biol Oceanogr 6:375-382

Kovala PE, Larrance JD (1966) Computation of phytoplankton cell numbers, cell volumes, cell surface and plasma vol- ume per litre from microscopial counts. Univ Wash Publ Oceanogr 38:1-21

Leck C, Larsson U, Bågander LE, Johansson S, Hajdu S (1989) DMS in the Baltic Sea: annual variability in relation to biological activity. J Geophys Res 95:3353-3363

Lovelock JE, Maggs RJ, Rasmussen RA (1972) Atmospheric dimethyl sulphide and the natural sulphur cycle. Nature 237:452-453

Malin G, Turner S, Liss P, Holligan P, Harbour D (1993) Dimethylsulphide and dimethylsulphoniopropionate in the Northeast Atlantic during the summer coccolithophore bloom. Deep Sea Res Part A 40:1487-1508

Malin G, Liss PS, Turner SM (1994) Dimethyl sulfide: production and atmospheric consequences. In: Green JC, Leadbeater BSC (eds) The haptophyte algae. Clarendon, Oxford, p 303-320

Malin G, Wilson WH, Bratbak G, Liss PS, Mann NH (1998) Elevated production of dimethylsulfide resulting from viral infection of Phaeocystis pouchetii. Limnol Oceanogr 43:1389-1393

Massana R, Gasol JM, Bjornsen PK, Blackburn N and 5 others (1997) Measurement of bacterial size via image analysis of epifluorescence preparations: description of an inexpensive system and solutions to some of the most common problems. Sci Mar 61:397-407

Matrai PA, Keller MD (1993) Dimethylsulfide in a large-scale coccolithophore bloom in the Gulf of Maine. Cont Shelf Res 13:831-843

Nightingale PD, Malin G, Law CS, Watson AJ and 4 others (2000) In situ evaluation of air-sea gas exchange parameterizations using novel conservative and volatile tracers. Global Biogeochem Cycles 14:373-387

Niki T, Kunugi M, Otsuki A (2000) DMSP-lyase activity in five marine phytoplankton species: its potential importance in DMS production. Mar Biol 136:759-764

Noordkamp DJB, Gieskes WWC, Gottschal JC, Forney LJ, van Rijssel M (2000) Acrylate in Phaeocystis colonies does not affect the surrounding bacteria. J Sea Res 43:287-296

Parsons TR, Maita Y, Lalli CM (1984) Plant pigments. In: Parsons TR, Maita Y, Lalli CM (eds) A manual of chemical and biological methods for seawater analysis. Pergamon, Oxford, p 99-112

Pedrós-Alió C, Calderón-Paz JI, Guixa-Boixereu N, Estrada M, Gasol JM (1999) Bacterioplankton and phytoplankton biomass and production during summer stratification in the northwestern Mediterranean Sea. Deep Sea Res Part A 46:985-1019

Sieburth JM (1960) Acrylic acid an 'antibiotic' principle in Phaeocystis blooms in Antarctic waters. Science 132: 676-677

Simó R, Pedrós-Alió C (1999a) Role of vertical mixing in controlling the oceanic production of dimethyl sulphide. Nature 402:396-399

Simó R, Pedrós-Alió C (1999b) Short-term variability in the open ocean cycle of dimethylsulfide. Global Biogeochem Cycles 13:1173-1181

Slezak DM, Puskaric S, Herndl GJ (1994) Potential role of acrylic acid in bacterioplankton communities in the sea. Mar Ecol Prog Ser 105:191-197

Sokal RR, Rohlf FJ (1995) Biometry. WH Freeman, New York

Stefels J (2000) Physiological aspects of the production and conversion of DMSP in marine algae and higher plants. J Sea Res 43:183-197

Stefels J, van Boekel WHM (1993) Production of DMS from dissolved DMSP in axenic cultures of the marine phytoplankton species Phaeocystis sp. Mar Ecol Prog Ser 97: $11-18$ 
Stefels J, Dijkhuizen L, Gieskes WWC (1995) DMSP-lyase activity in a spring phytoplankton bloom off the Dutch coast related to Phaeocystis sp abundance. Mar Ecol Prog Ser 123:235-243

Steinke M, Daniel C, Kirst GO (1996) DMSP lyase in marine macro- and microalgae: intraspecific differences in cleavage activity In: Kiene RP, Visscher PT, Keller MD, Kirst GO (eds) Biological and environmental chemistry of DMSP and related sulfonium compounds. Plenum, New York, p 317-324

Steinke M, Wolfe GV, Kirst GO (1998) Partial characterisation of dimethylsulfoniopropionate (DMSP) lyase isozymes in 6 strains of Emiliania huxleyi. Mar Ecol Prog Ser 175: 215-225

Steinke M, Malin G, Turner SM, Liss PS (2000) Determinations of dimethylsulfoniopropionate (DMSP) lyase activity using headspace analysis of dimethylsulfide (DMS). J Sea Res 43:233-244

Steinke M, Malin G, Gibb SW, Burkill PH (2002) Vertical and temporal variability of DMSP lyase activity in a coccolithophorid bloom in the northern North Sea. Deap-Sea Res Part II (in press)

Turner SM, Malin G, Liss PS, Harbour DS, Holligan PM (1988) The seasonal variation of dimethyl sulfide and dimethylsulfoniopropionate concentrations in nearshore waters. Limnol Oceanogr 33:364-375

Editorial responsibility: William Li, Dartmouth, Nova Scotia, Canada
Turner SM, Malin G, Bagander LE, Leck C (1990) Interlaboratory calibration and sample analysis of dimethyl sulphide in water. Mar Chem 29:47-62

van den Berg AJ, Turner SM, van Duyl FC, Ruardij P (1996) Model structure and analysis of dimethylsulphide (DMS) production in the southern North Sea considering phytoplankton dimethylsulphoniopropionate- (DMSP) lyase and eutrophication effects. Mar Ecol Prog Ser 145: 233-244

van der Maarel MJEC, Aukema W, Hansen TA (1996) Purification and characterization of a dimethylsulfoniopropionate cleaving enzyme from Desulfovibrio acrylicus. FEMS Microbiol Lett 143:241-245

Wilson WH, Turner S, Mann NH (1998) Population dynamics of phytoplankton and viruses in a phosphate-limited mesocosm and their effect on DMSP and DMS production. Est Coast Shelf Sci 46:49-59

Wolfe GV (2000) The chemical defense ecology of marine unicellular plankton: constraints mechanisms and impacts. Biol Bull 198:225-244

Wolfe GV, Steinke M (1996) Grazing-activated production of dimethyl sulfide (DMS) by two clones of Emiliania huxleyi. Limnol Oceanogr 41:1151-1160

Wolfe GV, Steinke M, Kirst GO (1997) Grazing-activated chemical defence in a unicellular marine alga. Nature 387 : 894-897

Submitted: June 15, 2001; Accepted: November 13, 2001 Proofs received from author(s): January 14, 2002 